\author{
JOURNAL OF MARINE RESEARCH AND TECHNOLOGY \\ journal homepage: https://ojs.unud.ac.id/index.php/JMRT \\ ISSN: $2621-0096$ (electronic); 2621-0088 (print)
}

\title{
Skrining Fitokimia Ekstrak Daun Mangrove Rhizophora mucronata dan Rhizophora apiculata yang Dikoleksi dari Kawasan Mangrove Desa Tuban, Bali
}

\author{
Alanis Ismi Akasia ${ }^{a}$, I Dewa Nyoman Nurweda Putra ${ }^{\mathrm{a}}$, dan I Nyoman Giri Putra ${ }^{* a}$ \\ ${ }^{a}$ Program Studi Ilmu Kelautan, Fakultas Kelautan dan Perikanan, Universitas Udayana, Bali, Indonesia \\ *Corresponding author, email: nyomangiriputra@unud.ac.id
}

\section{ARTICLE INFO}

\section{ABSTRACT}

\section{Article history:}

Received: August $7^{\text {th }} 2020$

Received in revised form: August $25^{\text {th }} 2020$

Accepted: October $8^{\text {th }} 2020$

Available online: February $28^{\text {th }} 2021$

Keywords:

Mangrove

Rhizophora apiculata

Rhizophora mucronata

Secondary metabolites

\begin{abstract}
The content of secondary metabolite compounds in marine plants, especially mangrove has a certain bioactivity. Therefore, this study was aims to determine the content of secondary metabolites in the mangrove leaf extract of Rhizophora apiculata and Rhizophora mucronata. This study was conducted on January-April 2020. Sampling locations were carried out in the Mangrove Conservation Area of Tuban Village, Bali. In this study, samples were collected in the form of old leaves. The samples were taken in three sites and in each sites, $500 \mathrm{gr}$ of leaves were collected randomly for each species. Therefore, in total we have $1.5 \mathrm{~kg}$ of leaves for each species. Samples are then extracted and tested to determine the content of secondary metabolites. The results showed the content of secondary metabolites in the leaves of $R$. apiculata mangrove were phenols, alkaloids, flavonoids, tannins, saponins, steroids while $R$. mисronata contained phenols, flavonoids, tannins, saponins, terpenoids.
\end{abstract}

2021 JMRT. All rights reserved.

\section{Pendahuluan}

Salah satu masalah yang dihadapi negara maju maupun berkembang adalah semakin meningkatnya tingkat resistensi bakteri terhadap antibiotik (Ariani dan Niah, 2019). Upaya yang dapat dilakukan untuk menghadapi permasalahan tersebut adalah mengganti penggunaan antibiotik dengan bahan ramah lingkungan seperti tumbuhan yang mengandung senyawa tertentu.

Mangrove merupakan komunitas tumbuhan yang hidup di daerah intertidal (Supriharyono, 2000). Menurut Suciati et al. (2012), mangrove mengandung senyawa bioaktif antibakteri. Selain itu, mangrove dapat digunakan sebagai obat tradisional, anti jamur, anti virus, anti kanker dan anti tumor (Ikhtiani et al., 2018). Menurut Saptiani et al. (2011), kandungan senyawa antibakteri banyak terkandung pada bagian daun mangrove. Hal ini disebabkan oleh terjadinya proses fotosintesis pada daun sehingga senyawa kimia banyak disintesis.

Provinsi Bali memiliki hutan mangrove yang tersebar di tiga lokasi yaitu Taman Hutan Raya (TAHURA) Ngurah Rai, Nusa Lembongan, dan Taman Nasional Bali Barat (Pratama, 2019). TAHURA Ngurah Rai merupakan kawasan dengan luasan hutan mangrove yang terbesar yaitu seluas $1373,5 \mathrm{Ha}$. Terdapat 12 desa disekitar TAHURA, salah satunya adalah Desa Tuban (UPT Tahura Ngurah Rai, 2012). Masyarakat di Desa Tuban memanfaatkan ekosistem mangrove sebagai sumber kehidupan (Lugina et al., 2017) seperti tujuan wisata dan budidaya kepiting. Namun, kawasan ini juga merupakan muara dari beberapa sungai yang berpotensi membawa bahan pencemar seperti sampah dan logam berat ke dalam perairan (Puspasari, 2014). Selain itu, adanya pembangunan tol disekitar kawasan TAHURA Ngurah
Rai juga menyebabkan tekanan yang sangat besar bagi hutan mangrove (Wiyanto dan Faiqoh, 2015). Hal tersebut akan menjadi faktor yang dapat memicu bagi tumbuhan mangrove untuk beradaptasi dan menghasilkan senyawa sebagai sistem pertahanan terhadap lingkungan (Subhashini et al., 2013).

Kandungan senyawa metabolit sekunder pada setiap tumbuhan memiliki bioaktifitas tertentu sehingga diperlukan identifikasi lebih lanjut. Salah satu metode yang digunakan untuk mengidentifikasi kandungan senyawa metabolit sekunder adalah skrining fitokimia. Skrining fitokimia dilakukan dengan melihat reaksi pengujian warna dengan menggunakan pereaksi tertentu (Kristianti et al., 2008).

Penelitian terkait kandungan senyawa pada beberapa jenis mangrove telah banyak dilakukan, diantaranya penelitian yang dilakukan oleh Rahmania et al. (2018) dengan menggunakan beberapa spesies mangrove seperti Avicennia alba dan Sonneratia alba. Pada penelitian ini, mangrove yang akan dilakukan skrining fitokimia adalah mangrove jenis $R$. mucronata dan $R$. apiculata. Kandungan senyawa metabolit sekunder berbeda pada setiap jenis mangrove karena senyawa ini tidak selalu dihasilkan pada setiap tumbuhan tetapi akan dihasilkan pada saat dibutuhkan oleh tumbuhan atau pada fase-fase tertentu (Sudjadi, 2010). Tujuan dari penelitian ini adalah untuk mengetahui kandungan senyawa metabolit sekunder yang terkandung dalam ekstrak daun mangrove $R$. apiculata dan $R$. mucronata. 


\section{Metode}

\subsection{Waktu dan tempat}

Penelitian dilaksanakan pada bulan Januari - April 2020. Lokasi pengambilan sampel daun mangrove $R$. mucronata dan $R$. apiculata dilakukan di Kawasan Konservasi Mangrove Desa Tuban, Kecamatan Kuta, Bali (Gambar 1). Proses ekstraksi dan uji fitokimia dilakukan di Laboratorium Kimia Organik, Fakultas Matematika dan Ilmu Pengetahuan Alam Universitas Udayana.

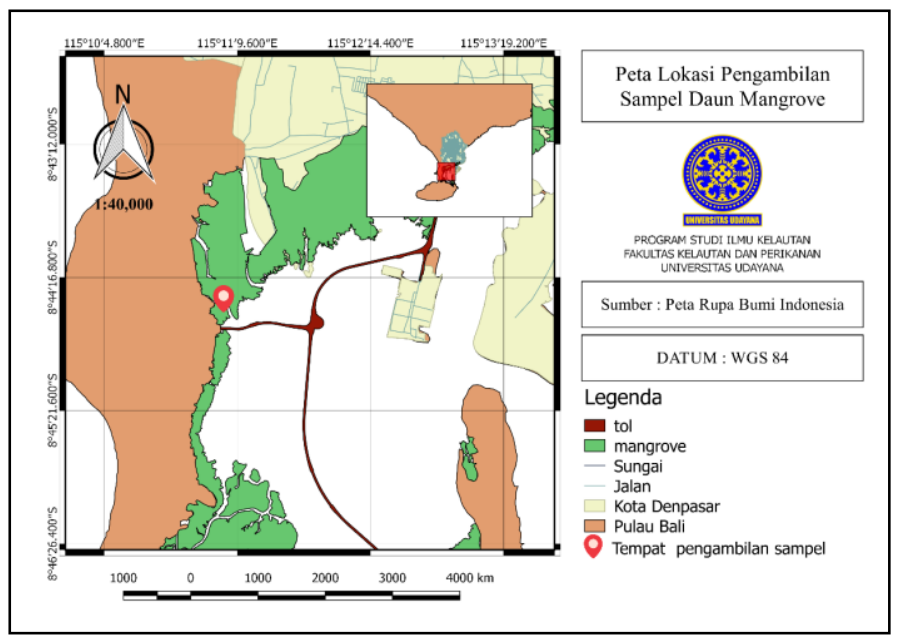

Gambar 1. Peta lokasi pengambilan sampel daun mangrove

\subsection{Metode Pengambilan Sampel Daun Mangrove}

Pengambilan sampel mangrove $R$. mucronata dan $R$. apiculata dilakukan secara random dengan mengambil bagian daun tua dengan kondisi utuh. Ciri-ciri daun tua yaitu daun berwarna hijau dan kemerahan juga memiliki tekstur yang keras atau kaku (Noor et al., 1999). Letak daun tua adalah dekat pangkal dahan serta daunnya telah meluas secara penuh (Pribadi, 1998). Masing-masing spesies diambil daunnya hingga sebanyak $1,5 \mathrm{~kg}$. Jarak pengambilan sampel daun mangrove dilakukan setiap 10 meter dan jumlah pengambilan sebanyak 500gr pada masing-masing spesies di setiap titik pengambilan.

\subsection{Ekstraksi Daun Mangrove}

Daun mangrove yang telah diambil di lapangan, dicuci terlebih dahulu hingga bersih, kemudian dijemur dengan bantuan cahaya matahari hingga kering. Daun mangrove yang telah kering tersebut, dihaluskan menggunakan blender, kemudian diayak. Proses ekstraksi dilakukan pada daun yang telah halus tersebut. Ekstraksi daun mangrove dilakukan dengan metode maserasi. Maserasi dilakukan dengan cara merendam serbuk daun mangrove menggunakan pelarut metanol dengan perbandingan antara daun dengan metanol 1:3 selama 3 x24 jam (Danata, 2014). Daun mangrove ditimbang masing masing sebanyak $300 \mathrm{gr}$ lalu dimasukkan ke dalam wadah maserasi kemudian direndam dengan metanol sebanyak $900 \mathrm{ml}$. Metanol digunakan karena secara umum pelarut ini paling banyak digunakan dalam proses isolasi senyawa organik karena dapat melarutkan hampir seluruh golongan metabolit sekunder (Darwis, 2000 dalam Oktavianus, 2013). Tahap selanjutnya adalah proses penyaringan sampel menggunakan kertas saring whatman 41 lalu dievaporasi menggunakan rotary evaporator pada suhu $50^{\circ} \mathrm{C}$ hingga menghasilkan ekstrak daun mangrove kental. Proses evaporasi dilakukan hingga diperoleh ekstrak kental yang ditandai dengan sudah tidak ada lagi pelarut yang menetes pada labu penampung.
Waktu yang dibutuhkan untuk menghasilkan 1 liter ekstrak daun mangrove pada saat proses evaporasi kurang lebih 3 jam.

Setelah didapatkan hasil ekstraksi kemudian dihitung nilai rendemennya. Rendemen diperoleh dari perbandingan berat ekstrak yang didapat dibagi dengan berat awal sampel yang digunakan. Rendemen menyatakan efektivitas suatu pelarut terhadap bahan yang diekstraksi namun tidak menunjukkan tingkat aktivitas ekstrak tersebut (Sari, 2008). Rendemen hasil ekstraksi dapat dihitung menggunakan rumus sebagai berikut :

$$
\text { Rendemen }=\frac{\text { Berat ekstrak }}{\text { Berat awal sampel }} \times 100 \%
$$

\subsection{Uji Fitokimia}

Uji fitokimia dilakukan untuk mengetahui ada atau tidaknya kandungan senyawa metabolit sekunder yang terkandung dalam ekstrak mangrove $R$. mucronata dan $R$. apiculata. Uji fitokimia dilakukan dengan mengamati perubahan warna yang terjadi setelah ekstrak diberi larutan uji (Prihanto et al., 2011).

\section{a) Uji Alkaloid}

Uji alkaloid dilakukan dengan mencampurkan $2 \mathrm{ml}$ ekstrak daun mangrove yang ditambahkan dengan $2 \mathrm{ml} \mathrm{HCl}$ dan pereaksi Meyer, kemudian diamati perubahan warna yang terjadi. Indikator positif dari uji alkaloid adalah terbentuknya endapan putih.

\section{b) Uji Fenolik}

Uji Fenolik dilakukan dengan cara menambahkan $2 \mathrm{ml}$ ekstrak daun mangrove yang ditambahkan $\mathrm{FeCl} 3$ 1\%, kemudian diamati perubahan warna yang terjadi. Indikator positif dari uji fenol adalah terbentuknya warna biru kehitaman.

\section{c) Uji Saponin}

Uji Saponin dilakukan dengan cara mencampurkan $2 \mathrm{ml}$ ekstrak daun mangrove kemudian ditambahkan $5 \mathrm{ml}$ aquades, selanjutnya dikocok hingga terbentuk busa stabil, kemudian ditambahkan 1 tetes $\mathrm{HCl} 2 \mathrm{~N}$. Indikator positif dari uji saponin adalah terbentuknya busa yang tetap stabil.

\section{d) Uji Flavonoid}

Uji Flavonoid dilakukan dengan cara mencampurkan beberapa $\mathrm{ml}$ ekstrak daun mangrove dengan $5 \mathrm{ml}$ etanol, kemudian ditambahkan beberapa tetes $\mathrm{HCl}$ pekat dan 1,5 gr magnesium. Indikator positif dari uji flavonoid adalah terbentuknya warna merah.

\section{e) Uji Tanin}

Uji Tanin dilakukan dengan cara mencampurkan $2 \mathrm{ml}$ ekstrak daun mangrove dengan $\mathrm{FeCl} 3$ setelah itu ditambahkan 2-3 tetes larutan $\mathrm{H} 2 \mathrm{SO} 4$ kemudian diamati perubahan warna yang terjadi. Indikator positif dari uji tanin adalah terbentuknya larutan berwarna kuning kecoklatan.

\section{f) Uji Steroid dan Terpenoid}

Uji Triterpenoid dan Steroid dilakukan dengan cara menambahkan filtrat pada plat tetes dan dibiarkan sampai kering, kemudian ditambahkan satu tetes asam asetat anhidrida dan satu asam sulfat pekat (Pereaksi Liebermann Burchard). Indikator positif dari uji terpenoid adalah terbentuknya warna merah atau ungu dan positif steroid apabila larutan berwarna biru atau hijau.

Hasil uji yang dilakukan disajikan dalam bentuk tabel dan dinyatakan dengan nilai (+) apabila terdapat kandungan senyawa 
metabolit sekunder pada ekstrak daun mangrove, sebaliknya dinyatakan dengan nilai (-) apabila tidak.

\section{Hasil dan Pembahasan}

\subsection{Ekstrak Daun Mangrove Rhizophora apiculata dan Rhizophora mucronata}

Hasil ekstraksi daun mangrove dengan metode maserasi menghasilkan ekstrak $R$. apiculata $(\mathrm{Ra})$ sebanyak $18.2206 \mathrm{gr}$ dan R. mucronata $(\mathrm{Rm})$ sebanyak 21.2608 gr. Ekstrak dari kedua daun berwarna hijau tua dengan tekstur kental seperti pasta yang dapat dilihat pada (Gambar 2).

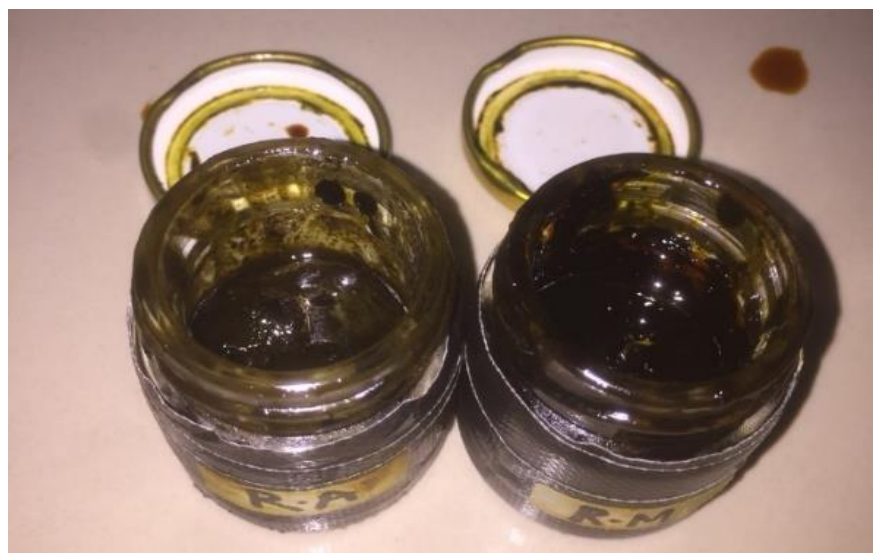

Gambar 2. Ekstrak daun mangrove $R$. apiculata (Ra) dan $R$. mucronata $(\mathrm{Rm})$

Rendemen hasil ekstraksi dari daun $R$. mucronata adalah sebesar $6,4 \%$ dan $R$. apiculata sebesar 5,5\%. Perbedaan nilai rendemen yang dihasilkan oleh kedua daun tersebut dikarenakan adanya perbedaan kemampuan pelarut yang berdifusi ke dalam sel. Nilai rendemen yang semakin besar menandakan semakin efektif ekstrak yang dapat dimanfaatkan (Priyanto, 2012). Menurut Suciati et al. (2012), komponen yang terbawa pada saat proses ekstraksi merupakan komponen yang sesuai dengan pelarutnya sehingga jenis pelarut yang digunakan dapat memengaruhi jumlah rendemen yang didapatkan.

Jenis pelarut yang digunakan dalam penelitian ini adalah metanol. Metanol merupakan pelarut yang paling banyak digunakan dalam proses ektraksi, karena kemampuannya yang dapat melarutkan hampir seluruh golongan metabolit sekunder baik yang bersifat polar maupun non polar (Darwis, 2000) dalam (Oktavianus, 2012).

\subsection{Fitokimia Mangrove Rhizophora apiculata dan Rhizophora mucronata}

Hasil uji fitokimia pada masing-masing spesies mangrove dapat dilihat pada (Tabel 1).

Tabel 1. Kandungan senyawa metabolit sekunder daun mangrove $R$. apiculata dan R. mucronata

\begin{tabular}{ccc}
\hline Senyawa & \multicolumn{2}{c}{ Daun Mangrove } \\
Metabolit & $R$. apiculata & $R$. mucronata \\
Sekunder & + & + \\
\hline Fenol & + & - \\
Alkaloid & + & + \\
Flavonoid & + & + \\
Tanin & + & + \\
Saponin & - & + \\
Terpenoid & + & - \\
Steroid & & \\
\hline
\end{tabular}

$R$. apiculata mengandung lebih banyak senyawa metabolit sekunder dibanding $R$. mucronata berdasarkan uji fitokimia. $R$. apiculata positif mengandung fenol, alkaloid, flavonoid, tanin, saponin, steroid dan negatif mengandung senyawa terpenoid, sedangkan $R$. mucronata positif mengandung fenol, flavonoid, tanin, saponin, terpenoid dan negatif mengandung alkaloid dan steroid.

Senyawa metabolit sekunder yang terkandung dalam daun mangrove $R$. apiculata dan $R$. mucronata tergolong banyak, hal ini menunjukkan bahwa tanaman ini hidup pada lingkungan yang ekstrim (Sarker et al., 2006). Organisme dapat mensekresikan dan memproduksi senyawa metabolit sekunder sebagai respon terhadap lingkungan yang tidak ideal bagi kelangsungan hidupnya (Pharida and Jha, 2010).

\section{a) Fenol}

Senyawa fenolik merupakan senyawa metabolit sekunder yang memiliki fungsi biologis seperti antioksidan, antiflamasi dan sebagai antiseptik (Primadini, 2010). Hasil dari pengujian fenol terhadap $R$. apiculata dan $R$. mucronata keduanya menunjukkan hasil positif yang ditunjukkan dengan terbentuknya warna biru kehitaman atau hitam pekat. Ekstrak yang ditambahkan $\mathrm{FeCl} 3$ akan membentuk warna biru kehitaman karena $\mathrm{FeCl} 3$ akan bereaksi dengan gugus - $\mathrm{OH}$ aromatis (Haryati et al., 2015)

\section{b) Alkaloid}

Alkaloid merupakan golongan metabolit sekunder yang bersifat basa dan memiliki efek farmakologi pada manusia maupun hewan dan dalam dosis yang kecil, alkaloid sudah dapat memberikan aktivitas biologi yang cukup kuat (Endarini, 2016). Pengujian alkaloid dilakukan dengan menggunakan pereaksi pengendapan yaitu pereaksi Meyer yang mengandung kalium iodide dan merkuri klorida untuk memisahkan jenis alkaloid. Indikator positif dari pengujian alkaloid menggunakan pereaksi Meyer yaitu terbentuknya endapan putih setelah ditambahkan pereaksi.

Hasil uji alkaloid pada $R$. apiculata menghasilkan nilai positif karena terbentuknya endapan putih dan pada $R$. mucronata bernilai negatif karena tidak terbentuk endapan putih. Endapan putih yang dihasilkan setelah ekstrak ditambahkan pereaksi Meyer merupakan kompleks kalium-alkaloid. Alkaloid mengandung atom nitrogen yang memiliki pasangan electron bebas dan akan beraksi dengan ion logam $\mathrm{K}+$ dari pereaksi Meyer (McMurry, 2004). Menurut Priyanto (2012), kadar alkaloid yang dihasilkan oleh tumbuhan hijau tidak sama pada semua jaringan dan setiap tahap pertumbuhannya.

\section{c) Flavonoid}

Flavonoid merupakan senyawa metabolit sekunder yang termasuk kedalam kelompok fenol terbesar yang ditemukan di alam. Flavonoid berfungsi sebagai zat pengatur tumbuh, pengatur proses fotosintesis, zat antimikroba dan antivirus (Endarini, 2016). Senyawa ini biasanya dihasilkan oleh jaringan tumbuhan sebagai bentuk respon terhadap infeksi (Endarini, 2016). Hasil dari pengujian flavonoid terhadap $R$. apiculata dan $R$. mucronata keduanya menunjukkan hasil positif yang ditunjukkan dengan terbentuknya warna kuning atau oranye. Dari hasil tersebut menunjukkan bahwa metanol dapat melarutkan senyawa flavonoid. Hal ini diperkuat oleh pernyataan Markham (1988) bahwa flavonoid memiliki ikatan dengan gugus gula yang menyebabkan flavonoid lebih mudah larut dalam pelarut polar yaitu metanol. 


\section{d) Tanin}

Tanin merupakan senyawa bioaktif yang termasuk kedalam golongan polifenol (Wrasiati et al. 2011) dan berperan sebagai pertahanan terhadap mikroorganisme (Anggraito dkk, 2018). Tanin dapat larut dalam pelarut metanol berdasarkan uji fitokimia. Hasil dari pengujian tanin terhadap $R$. apiculata dan $R$. mucronata menunjukkan bahwa keduanya positif yang diperlihatkan dengan terbentuknya warna kuning kecoklatan. Kondisi tersebut terjadi karena senyawa tanin bersifat polar sehingga dapat larut dalam metanol yang memiliki sifat polar juga. Hal ini sesuai dengan pernyataan Prabowo (2014) yang menyatakan bahwa senyawa tanin memiliki banyak gugus $\mathrm{OH}$ sehingga tanin yang bersifat polar dapat larut dalam pelarut polar seperti metanol sehingga dapat terekstrak dengan baik.

\section{e) Saponin}

Saponin merupakan senyawa bioaktif yang termasuk kedalam golongan senyawa glikosida. Hasil dari pengujian saponin terhadap $R$. apiculata dan $R$. mucronata keduanya menunjukkan hasil positif yang ditunjukkan dengan terbentuknya busa atau buih yang tetap stabil setelah ditambahkan satu tetes $\mathrm{HCl}$. Hal ini sesuai dengan pernyataan Anggraito dkk, (2018), yang menyatakan bahwa saponin dapat membentuk larutan koloidal dalam air dan menghasilkan buih atau busa bila dikocok.

\section{f) Terpenoid}

Terpenoid merupakan bentuk senyawa dengan struktur yang besar dan diturunkan dari unit isoperna (C5). Terpen dan terpenoid pada tumbuhan menghasilkan minyak atsiri dan memiliki fungsi sebagai antiseptik, antimikroba, dan antibiotik (Heliawati, 2018). Hasil uji terpenoid pada $R$. apiculata menghasilkan nilai negatif karena tidak terbentuknya warna ungu kemerahan setelah ekstrak ditambahkan pereaksi LiebermanBurchard dan pada $R$. mucronata bernilai positif karena terbentuk warna ungu kemerahan setelah ditambahkan pereaksi LiebermanBurchard.

\section{g) Steroid}

Steroid merupakan kelompok senyawa metabolit sekunder yang strukturnya terdiri atas 17 karbon dan secara biogenetik berasal dari triterpen (Endarini, 2016). Steroid banyak terdapat dalam tumbuhan dan berasal dari molekul isoprene. Steroid terdapat dalam bentuk glikosida atau senyawa yang terdiri dari gula dan aglikon. Gula yang terikat dan bersifat polar akan larut dalam pelarut yang bersifat polar juga sehingga steroid dapat dilarutkan oleh metanol yang bersifat polar. Hasil uji steroid pada $R$. apiculata menghasilkan nilai positif karena terbentuknya warna hijau setelah ekstrak ditambahkan pereaksi LiebermanBurchard dan pada $R$. mucronata bernilai negatif karena tidak terbentuk warna hijau setelah ditambahkan pereaksi LiebermanBurchard. Warna hijau yang dihasilkan dari adanya reaksi antara asam asetat anhidrida dan asam sulfat pada pereaksi LiebermanBurchard.

Hasil pengujian fitokimia daun $R$. apiculata pada penelitian ini berbeda dengan yang didapatkan Yoswaty et al. (2019), dimana senyawa metabolit sekunder yang terkandung pada mangrove $R$. apiculata yang ada di Stasiun Kelautan, Desa Purnama, Dumai terdiri dari fenol, saponin, tanin, terpenoid, flavonoid namun tidak mengandung steroid. Jika dilihat pada (Tabel 1), perbedaan kedua penelitian ini terletak pada kandungan senyawa steroid dan terpenoidnya. Perbedaan hasil kandungan senyawa pada masing-masing spesies ini dikarenakan metabolit sekunder dihasilkan pada kondisi tertentu dan jumlah yang terbatas dan hanya untuk tujuan yang spesifik (Saifudin, 2014).

Ukuran partikel sampel, waktu, serta perbandingan pelarut dan sampel daun pada saat proses ekstraksi juga dapat memengaruhi perbedaan hasil senyawa metabolit sekunder sesuai dengan pernyataan dari Harborne (1987). Pada proses ekstraksi diketahui terdapat perbedaan, pada penelitian ini lama waktu maserasi adalah 3x24 jam sedangkan penelitian yang dilakukan oleh Yoswaty et al. (2019) adalah selama 2x24 jam. Perbedaan waktu maserasi akan berdampak pada jumlah kandungan metabolit sekunder. Hal ini sesuai dengan pernyataan dari Yudharini (2016) bahwa semakin lama proses ekstraksi maka semakin lama kontak antara simplisia dengan pelarut sehingga senyawa yang terekstrak lebih banyak.

Mangrove $R$. apiculata yang ada di Desa Tuban dan Desa Purnama mengandung metabolit sekunder yang tergolong banyak. Hal ini menunjukkan bahwa tekanan lingkungan kedua lokasi tersebut cukup tinggi salah satunya disebabkan oleh pencemaran. Tercemarnya lingkungan mangrove yang ada di Desa Purnama, Dumai diduga dipengaruhi oleh faktor antropogenik hal ini dikarenakan adanya aktivitas pelabuhan dan kawasan industri pengolahan minyak disekitar hutan mangrove (Syahrial et al., 2017). Menurut Amin et al. (2009) kegiatan antropogenik yang ada di Dumai berdampak pada peningkatan logam berat pada sedimen mangrove diantaranya adalah logam $\mathrm{Cd}, \mathrm{Cu}, \mathrm{Pb}, \mathrm{Zn}$, dan Ni (Tabel 2).

Tabel 2. Konsentrasi Logam Berat pada Sedimen di perairan Desa Dumai

\begin{tabular}{ccc}
\hline $\begin{array}{c}\text { Logam } \\
\text { Berat* }\end{array}$ & $\begin{array}{c}\text { Konsentrasi } * \\
(\mathrm{mg} / \mathrm{kg})\end{array}$ & $\begin{array}{c}\text { Baku mutu (Kepmen LH } \\
\text { No.51 Tahun 2004) } \\
(\mathrm{mg} / \mathrm{kg})\end{array}$ \\
\hline $\mathrm{Cd}$ & 0.001 & 0.001 \\
$\mathrm{Cu}$ & 0.009 & 0.008 \\
$\mathrm{~Pb}$ & 0.028 & 0.008 \\
$\mathrm{Zn}$ & 0.056 & 0.05 \\
$\mathrm{Ni}$ & 0.011 & 0.05 \\
\hline
\end{tabular}

*Data sekunder, Amin et al. (2009)

Jika dilihat dari tabel 2, konsentrasi logam yang ada pada sedimen di perairan Desa Dumai telah melewati baku mutu standar dimana dapat diasumsikan bahwa kondisi lingkungan tersebut sudah tercemar, mangrove kemudian akan memproduksi sejumlah metabolit sekunder sebagai bentuk adaptasi. Mangrove yang ada di Desa Tuban, Bali juga diduga dipengaruhi oleh faktor antropogenik. Kawasan ini termasuk kedalam kawasan wisata dimana terdapat restoran laut dan juga wisata air selain itu kawasan ini juga merupakan kawasan buangan limbah yang secara tidak langsung dapat mempengaruhi ekosistem mangrove (Ulfa, 2018). Menurut Puspasari (2014) kegiatan antropogenik yang terjadi di sepanjang daerah aliran Sungai Badung yang bermuara ke Tahura Ngurah Rai berdampak pada peningkatan logam berat di perairan. Logam berat yang terkandung dalam perairan diantaranya adalah $\mathrm{Cu}$ dan $\mathrm{Zn}$ (Tabel 3).

Tabel 3. Konsentrasi Total Logam $\mathrm{Cu}$ dan $\mathrm{Zn}$ dalam Perairan

\begin{tabular}{ccc}
\hline $\begin{array}{c}\text { Logam } \\
\text { Berat* }\end{array}$ & $\begin{array}{c}\text { Konsentrasi } * \\
(\mathrm{mg} / \mathrm{kg})\end{array}$ & $\begin{array}{c}\text { Baku mutu (Kepmen } \\
\text { LH No.51 Tahun } \\
2004)(\mathrm{mg} / \mathrm{kg})\end{array}$ \\
\hline $\mathrm{Cu}$ & 0.001 & 0.001 \\
$\mathrm{Zn}$ & 0.009 & 0.008 \\
\hline
\end{tabular}

*Data sekunder, (Puspasari, 2014) 
Berdasarkan tabel 3, dapat diketahui bahwa konsentrasi logam $\mathrm{Cu}$ dan $\mathrm{Zn}$ sudah melebihi ambang batas konsentrasi logam berat di perairan laut. Hal ini menunjukkan bahwa perairan yang ada di Tahura Ngurah Rai sudah tercemar. Adanya pengaruh antropogenik akan membuat mangrove melakukan adaptasi dengan cara mempertahankan diri dari lingkungannya dengan memproduksi metabolit sekunder. Menurut Gomez-Parra et al. (2000) gangguan antropogenik seperti adanya buangan limbah rumah tangga dan industri berpengaruh pada kandungan senyawa metabolit sekunder pada organisme sebagai bentuk adaptasi lingkungan tercemar.

Parameter lingkungan mangrove $R$. apiculata yang di Desa Tuban, Bali (Andika, 2018) dan $R$. apiculata di Stasiun kelautan Desa Purnama Kota Dumai, Riau (Yoswaty et al., 2019) menunjukkan bahwa terdapat perbedaan pada suhu, $\mathrm{pH}$ dan salinitas pada kedua lokasi tersebut (Tabel 4).

Tabel 4. Parameter Lingkungan $R$. apiculata di Desa Tuban dan Dumai

\begin{tabular}{ccc}
\hline \multirow{2}{*}{ Parameter } & \multicolumn{2}{c}{ Lokasi Penelitian } \\
\cline { 2 - 3 } Lingkungan & $\begin{array}{c}\text { Desa Tuban, } \\
\text { Bali }^{\mathrm{a}}\end{array}$ & $\begin{array}{c}\text { Desa Purnama, } \\
\text { Dumai }\end{array}$ \\
\hline Suhu $\left({ }^{\circ} \mathrm{C}\right)$ & 28.4 & 29.8 \\
$\mathrm{pH}$ & 7.7 & 7.4 \\
Salinitas $(\%)$ & 20.17 & 21.3 \\
\hline
\end{tabular}

*Data sekunder, ${ }^{\text {a }}$ (Andika, 2018), ${ }^{\text {b }}$ Yoswaty et al. (2019).

Mangrove $R$. apiculata yang berada di Desa Tuban tidak ditemukan adanya senyawa terpenoid berbeda dengan di Stasiun Kelautan Dumai. Hal ini diduga karena adanya perbedaan salinitas pada kedua lokasi tersebut. Salinitas yang ada di Kawasan Desa Tuban memiliki salinitas yang relatif lebih rendah dari Stasiun Kelautan Dumai. Rendahnya salinitas di Desa Tuban menyebabkan senyawa terpenoid tidak dihasilkan hal ini sesuai dengan pernyataan Danata (2014), bahwa semakin tinggi salinitas maka mangrove dapat mengubah terpenoid agar dapat meningkatkan sistem pertahanan terhadap tekanan oksidatif dimana terpenoid ini nantinya akan berperan sebagai pelindung mangrove dari tekanan garam atau salinitas.

Sementara itu, hasil senyawa fitokimia mangrove $R$. mucronata pada penelitian ini juga berbeda dengan hasil penelitian Purwaningsih et al., (2013). Mangrove $R$. mucronata diketahui mengandung flavonoid, saponin, steroid, terpenoid, fenol namun negatif alkaloid, dan tanin. Jika dilihat pada tabel 1, perbedaan kedua penelitian ini terletak pada kandungan senyawa tanin dan steroid.

Perbedaan hasil senyawa yang diperoleh kemungkinan disebabkan oleh pelarut yang digunakan. Pada proses ekstraksi terdapat perbedaan, pada penelitian ini pelarut yang digunakan adalah metanol sedangkan penelitian yang dilakukan oleh Purwaningsih et al., (2013) menggunakan pelarut etanol. Perbedaan pelarut yang digunakan akan menghasilkan jumlah senyawa yang terekstrak. Hal ini sesuai dengan pernyataan dari Prabowo (2014) yang menyatakan bahwa perbedaan polaritas pada pelarut akan menyebabkan perbedaan jumlah kandungan senyawa yang didapatkan. Menurut Rasyidah (2018) metanol diketahui lebih polar dibandingkan dengan pelarut etanol. Selain itu, metanol merupakan pelarut yang paling banyak digunakan pada proses isolasi senyawa karena metanol dapat melarutkan hampir seluruh metabolit sekunder (Oktavianus, 2013).

Mangrove $R$. mucronata di kedua lokasi penelitian mengandung metabolit sekunder yang tergolong banyak hal ini menunjukkan bahwa kondisi lingkungan kedua lokasi tersebut sudah tercemar. Tercemarnya lingkungan mangrove yang ada di
Kepulauan Seribu diduga dipengaruhi oleh faktor antropogenik seperti buangan limbah cair dan aktivitas di perairan laut dekat kawasan mangrove. Sekitar 7,7 hektar ekosistem mangrove diketahui telah rusak dikarenakan pencemaran minyak yang terjadi disana (Kuncowati, 2010). Menurut Santoso (2005), adanya akumulasi cemaran minyak hasil buangan limbah cair oleh penduduk di daratan Jakarta telah berdampak pada vegetasi mangrove dimana lapisan minyak tersebut akan melapisi perakaran dan mengganggu sistem pernafasan mangrove. Sebagai salah satu mekanisme adaptasi terhadap kondisi lingkungan, mangrove akan memproduksi sejumlah metabolit sekunder (Sinulingga, 2015).

Berdasarkan penelitian yang dilakukan, diketahui bahwa parameter lingkungan, mangrove $R$. mucronata di Desa Tuban, Bali dan di Kepulauan Seribu menunjukkan perbedaan suhu, $\mathrm{pH}$ dan salinitas pada kedua lokasi tersebut (Tabel 5).

Tabel 5. Parameter Lingkungan $R$. mucronata di Desa Tuban dan Kepulauan Seribu

\begin{tabular}{ccc}
\hline \multirow{2}{*}{ Parameter } & \multicolumn{2}{c}{ Lokasi Penelitian } \\
\cline { 2 - 3 } Lingkungan & Desa Tuban, Bali ${ }^{\text {a }}$ & Kepulauan Seribu ${ }^{\mathrm{b}}$ \\
\hline Suhu $\left({ }^{\circ} \mathrm{C}\right)$ & 28.4 & 31 \\
$\mathrm{pH}$ & 7.7 & 7.1 \\
Salinitas $(\%$ oo $)$ & 20.17 & 31.3 \\
\hline *Data sekunder, ${ }^{\text {a }}$ (Andika, 2018), ${ }^{\text {b }}$ Syahrial et al. (2019).
\end{tabular}

Mangrove $R$. mucronata di Kepulauan Seribu tidak ditemukan adanya senyawa tanin berbeda dengan mangrove yang ada di Desa Tuban, Bali. Hal ini diduga karena adanya perbedaan $\mathrm{pH}$ pada kedua lokasi tersebut. Kawasan Desa Tuban memiliki pH yang relatif lebih tinggi dibandingkan Kepulauan Seribu. Rendahnya $\mathrm{pH}$ di Kepulauan Seribu menyebabkan senyawa tanin tidak dihasilkan. Sesuai dengan pernyataan Ehike dan LeGare (1993) dalam Danata (2014) bahwa semakin rendah kadar $\mathrm{pH}$ atau semakin bersifat asam dapat berpotensi berkurangnya produksi tanin pada tanaman. Tingginya salinitas yang ada di Kepulauan Seribu juga diduga menyebabkan senyawa tanin tidak dihasilkan, Iwuala et al., (2015) menyatakan bahwa salinitas dapat mengurangi dan menghambat produksi tanin. Suhu di kedua lokasi juga memiliki perbedaan. Tingginya suhu di Kepulauan seribu diduga menyebabkan senyawa tanin tidak diproduksi. Kondisi tersebut sesuai dengan pernyataan El-Lamey (2012), yang menyatakan bahwa suhu yang tinggi dapat menyebabkan perubahan struktur tanin yang berdampak pada berkurangnya kandungan tanin pada tumbuhan.

Mangrove $R$. mucronata yang berada di Kepulauan Seribu juga menunjukkan adanya senyawa steroid yang berbeda dengan mangrove yang ada di Desa Tuban, Bali. Kondisi tersebut diprediksi karena adanya perbedaan salinitas di kedua lokasi tersebut. Salinitas di Kepulauan Seribu lebih tinggi dibandingkan di Desa Tuban. Tingginya salinitas menyebabkan senyawa steroid akan dihasilkan. Hal ini sesuai dengan pernyataan Basyuni et al., (2009) bahwa salinitas dapat berpengaruh terhadap peningkatan konsentrasi steroid. Steroid berperan dalam memberikan toleransi terhadap salinitas, yaitu sebagai perlindungan dari salinitas yang tinggi pada mangrove. Adanya peningkatan konsentrasi garam akan menyebabkan senyawa steroid diproduksi dan bekerja untuk menetralkan tekanan osmotik atau sitotoksitas yang disebabkan oleh garam (Basyuni et al., 2012). 


\section{Kesimpulan}

Berdasarkan hasil penelitian disimpulkan bahwa hasil uji fitokimia pada mangrove $R$. apiculata positif mengandung fenol, alkaloid, flavonoid, tanin, saponin, steroid, serta negatif mengandung senyawa terpenoid, sedangkan pada $R$. mucronata positif mengandung fenol, flavonoid, tanin, saponin, terpenoid, serta negatif mengandung alkaloid dan steroid.

\section{Ucapan Terima Kasih}

Penulis mengucapkan terimakasih kepada seluruh pihak yang turut serta membantu dalam proses penelitian ini khususnya kepada dosen pembimbing yang telah memberikan saran dan masukan dalam proses penelitian ini dari awal hingga selesai. Penulis juga mengucapkan terimakasih kepada Kelompok Nelayan Wanasari yang telah memfasilitasi dalam pengambilan bahan sampel penelitian.

\section{Daftar Pustaka}

Amin, B., Ismail, A., Arshad, A. 2009. Gastropod Assemlages as Indicators of Sediment Metal Contamination in Mangroves of Dumai, Sumatra, Indonesia. Water Air Pollut 201:9-18

Andika, I. B. M. B., Kusmana, C., Nurjaya, I. W. 2018. Dampak pembangunan jalan tol Bali Mandara terhadap ekosistem mangrove di Teluk Benoa Bali. Journal of Natural Resources and Environmental Management 9(3): 641-657

Anggraito Y. U., Susanti. R., Iswari, R. S, Yuniastuti, A., Lisdiana, Nugrahaningsih, W. H., Habibah, N. A., Bintari, S. H. 2018. Metabolit sekunder dari tanaman. Semarang: Fakultas Matematika dan Ilmu Pengetahuan Alam. Universitas Negeri Semarang.

Ariani, N., Niah, R. 2019. Uji aktivitas antibakteri ekstrak etanol kulit pisang kapok (Musa paradisiaca formatypica) mentah secara in vitro. Jurnal Ilmiah Manuntung, 5(2), 161-166.

Basyuni, M., Baba, S., Inafuku, M., Iwasaki, H., Kinjo, K., Oku, H. 2009. Expression of terpenoid synthase mRNA and terpenoid content in salt stressed mangrove. J. Plant Physiol. 166, 1786-1800.

Basyuni, M., Baba, S., Kinjo, Y., Oku, H. 2012. Salinity increases the triterpenoid content of a salt secretor and a non-salt secretor mangrove. Aquatic Botany. 97(1), 17-23.

Darwis, D. 2000. Teknik dasar laboratorium dalam penelitian senyawa bahan alam hayati. Workshop Pengembangan Sumber Daya Manusia Dalam Bidang Kimia Organik Bahan Alam Hayati, FMIPA Universitas Andalas Pandang.

Danata, R. H. 2014. Analisis aktivitas antibakteri ekstrak daun mangrove Avicennia marina dari Kabupaten Trenggalek dan Kabupaten Pasuruan terhadap pertumbuhan Staphylococcus aureus dan Vibrio alginolyticus. Jurnal Kelautan 7(1): 12-19. ISSN: 1907-9931

El-Lamey, T. M. 2012. Effect of salinity on tannins content of Leucaena leucocephala (Lam.) de Wit. and Prosopis chilensis (Molina) stuntz and techniques for their reduction. Egypt. J. Bot 2nd International conference. pp. 51-63.

Endarini, L. H. 2016. Farmakognisi dan Fitokimia. Jakarta: Pusdik SDM Kesehatan. 215 hlm.

Gomez-Parra, A., Forja, J. M., DelValls, T. A., Saenz, I., Riba, I. 2000. Early contamination by heavy metals of the Guadalquivir estuary after the aznalcollar mining spills (SW Spain). Marine Pollution Bulletin, 40(12), 1115-1123.

Harborne, J. B. 1987. Metode Fitokimia: Penuntun Cara Modern Menganalisis Tumbuhan. Institut Teknologi Bandung, Bandung.

Haryati, E. S, Diba, F., Wahdina. 2015. Etnobotani tumbuhan berguna oleh masyarakat sekitar kawasan KPH model Kapuas Hulu. Jurnal Hutan Lestari 3(3): 434-445.

Heliawati, L. 2018. Kimia Organik Bahan Alam. Bogor: Universitas Pakuan Bogor. $180 \mathrm{hlm}$.

Ikhtiani, R., Zulkarnaen, N. F., Aminudin, M. F., Riwayati, I. 2018. Ekstraksi berbantu gelombang mikro senyawa bioformalin dari batang tumbuhan api-api (Avicennia marina). Prosiding SNST ke-9. Fakultas Teknik Universitas Wahid Hasyim.
Iwuala, E. N., Kanu, R. N., Eze, C. N. 2015. Effects of salinity and drought on the phytochemical production In Jatrophacurcas L. Bayero Journal of Pure and Applied Sciences. 8(2): $81-79$.

Kristianti, A. N., Aminah, N. S., Tanjung, M., Kurniadi, B. 2008. Buku Ajar: Fitokimia. Surabaya: Airlangga University Press.

Kuncowati. 2010. Pengaruh pencemaran minyak di laut terhadap ekosistem laut. Jurnal Aplikasi Pelayaran dan Kepelabuhan. 1(1): 18-22.

Lugina, M., Alviya, I., Indartik., Pribadi, M. A. 2017. Strategi keberlanjutan pengelolaan hutan mangrove di TAHURA Ngurah Rai Bali. Jurnal Analisis Kebijakan Kehutanan 14(1): 61-77

Markham, K. R. 1988. Cara Mengidentifikasi Flavonoid. diterjemahkan oleh Kosasih Padmawinata, Penerbit ITB, Bandung.

McMurry, J., Fay, R. C. 2004. McMurry Fay Chemistry. 4th edition. Belmont, CA.: Pearson Education International.

Noor, R. Y., Khazali, M., Suryadiputra, I. N. N. 1999. Panduan Pengenalan Mangrove di Indonesia. PHKA/WI-IP, Bogor.

Oktavianus, S. 2013. Uji daya hambat ekstrak daun mangrove jenis avicennia marina terhadap bakteri Vibrio parahaemolyticus. Skripsi. Universitas Hasanuddin, Makassar.

Prabowo, Y. 2014. Ekstraksi senyawa metabolit sekunder yang terdapat pada daun mangrove Xylocarpus granatum dengan pelarut yang berbeda. Repository UMRAH. https://jurnal.umrah.ac.id/?p=3357

Pribadi, R. 1998. The Eccology of Mangrove Vegetation in Bintuni Bay, Irian Jaya, Indonesia. Departemen of Biological and Molecular Science University of Stirling, Scotland. Bintuni, $108 \mathrm{p}$.

Prihanto, A. A., Firdaus, M., Nurdiani, R. 2011. penapisan fitokimia dan antibakteri ekstrak metanol mangrove (Excoecaria agallocha) dari Muara Sungai Porong. Berk. Penelitian Hayati. 17: 69-72.

Primadini, R. D. 2010. Uji aktivitas pengkhelatan besi pada ekstrak metanol tanaman obat pegagan (Centella asiatica), bunga merak (Caesalpinia pulcherimma) dan sendilaw udang (Commersonia batramia). Skripsi. Universitas Bengkulu.

Priyanto, R. A. 2012. Aktivitas antioksidan dan komponen bioaktif pada buah bakau (Rhizophora mucronata Lamk.). Skripsi. Institut Pertanian Bogor, Bogor.

Purwaningsih, S., Salamah, E., Sukarno, A. Y. P., Deskawati, E. 2013. Aktivitas antioksidan dari buah mangrove (Rhizophora mucronata Lamk.) pada suhu yang berbeda. JPHPI1 6(3): 199-206 . E-ISSN: 2354886X

Puspasari, D. A., Suprihatin, I. E., Panca Dewi, I. G. A. K. S. 2014. Spesiasi dan bioavailabilitas logam $\mathrm{Cu}$ dan $\mathrm{Zn}$ dalam perairan dan sedimen muara Sungai Badung pada jalur Taman Hutan Raya Ngurah Rai Denpasar Bali. Jurnal Kimia. 8(2): 153-158.

Rahmania N, Herpandi, Rozirwan. 2018. Pythochemical Test of Mangrove Avicennia alba, Rhizophora apiculata and Sonneratia alba from Musi River Estuary, South Sumatera. Biovalentia: Biological Research Journal 4(2):1-6 e-ISSN: $2477-1392$

Rasyidah, U. M. 2018. Uji aktivitas sitotoksik ekstrak etanol dan metanol Spirulina platensis L. terhadap sel WiDr. Skripsi. Universitas Muhammadiyah Surakarta.

Saifudin, A. 2014. Senyawa Alam Metabolit Sekunder (Teori, Konsep, dan Teknik Pemurnian), Yogyakarta: Deepublish. $118 \mathrm{hlm}$.

Santoso, N. 2005. Pelestarian vegetasi lokal dalam rangka pengembangan tata ruang kepulauan seribu. Media Konservasi 10(1): 7-11.

Saptiani, G., Prayitno, S. B., Anggoro, S. 2011. Daya hambat ekstrak jeruju (Acanthus ilicifolius) terhadap pertumbuhan Vibrio harveyi. Simposium Nasional Kimia Bahan Alam XIX (SimNasKBA-2011). Himpunan Kimia Bahan Alam. Samarinda.

Sari D. K. 2008. Penapisan antibakteri dan inhibitor topoisomerase I dari Xylocarpus granatum. Tesis. Sekolah Pasca Sarjana, Institut Pertanian Bogor. Bogor.

Sarker, S. D., Latif, Z., Gray, A. L. 2006. Natural Product Isolation. New Jersey: Humana Press. 515 pp.

Sinulingga, E. K., Basyuni, M., Yunasfi. 2015. Respons pertumbuhan tanaman dan konsentrasi rantai panjang polyisoprenoid terhadap variasi naungan dan salinitas pada mangrove Sonneratia Alba Smith. Peronema Forestry Science Journal, 4(3): 241-253.

Subhashini, P., Dilipan, E., Thangaradjou, T., Papenbrock, J. 2013. Bioactive natural products from marine angiosperms: abundance and functions. Natural products and bioprospecting. 3(4): 129-136.

Suciati, A., Wardiyanto., Sumino. 2012. Efektifitas ekstrak daun Rhizophora mucronata dalam menghambat pertumbuhan Aeromonas salmonicida dan Vibrio harveyi. Jurnal Rekayasa dan Teknologi Budidaya Perairan. 1(1): 1-8 ISSN: 2302-3600.

Sudjadi. 2010. Kimia Farmasi Analisis. Yogyakarta: Pustaka Pelajar. 122 hlm. Supriharyono. 2000. Pelestarian dan Pengelolaan Sumber Daya Alam di Wilayah Pesisir Tropis. Jakarta: Gramedia. 246 hlm. 
Syahrial., Saleky, D., Pangaribuan, R. D., Leatemia, S. P. O., Putri, N. R. 2019. Status biota penempel pasca penanaman mangrove Rhizophora spp. Di Kepulauan Seribu: Studi Kasus Filum Moluska. Journal of Fisheries and Marine Research. 3(2): 172-182.

Ulfa, M., Julyantoro, P. G. S., Sari, A. H. W. 2018. Keterkaitan komunitas makrozoobentos dengan kualitas air dan substrat di ekosistem mangrove Taman Hutan Raya Ngurah Rai Bali. Journal of Marine and Aquatic Science 4(2): 179-190.

UPT Taman Hutan Raya Ngurah Rai. 2012. Wisata alam taman hutan raya. Denpasar: UPT Taman Hutan Raya Ngurah Rai.

Wrasiati, L. P, Hartati, A., Yuarini, D. A. A. 2011. Kandungan senyawa bioaktif dan karakteristik sensoris ekstrak simplisia bunga kamboja (Plumeria sp.) Jurnal Biologi. 15(2): 39-43.

Yoswaty D., Nursyirwani., Nurrachmi, I., Marcel, A. 2019. Uji antibakteri dan fitokimia dari batang dan daun mangrove Rhizophora apiculata terhadap bakteri patogen. Semnaskan-UGM XVI. Manajemen Sumberdaya Perikanan.

Yudharini, G. A. K. F., Suryawan, W., Wartini, N. M. 2016. Pengaruh perbandingan bahan dengan pelarut dan lama ekstraksi terhadap rendemen dan karakteristik ekstrak pewarna dari buah pandan (Pandanus tectorius). Jurnal Rekayasa dan Manajemen Agroindustri 4(3): 36-46. 